\title{
脚車輪分離型ロボットの大不整地適応歩容*
}

\author{
(第 2 報, 段差上り歩容編)
}

\author{
中嶋秀 朗*1, 中野栄二*1

\section{Adaptive Gait for Large Rough Terrain of a Leg-wheel Robot (2nd Report, Gait for an Upward Step)}

\author{
Shuro NAKAJIMA*2 and Eiji NAKANO
}

*2 The Department of Advanced Robotics, Chiba Institute of Technology, 2-17-1 Tsudanuma, Narashino-shi, Chiba, 275-0016 Japan

\begin{abstract}
A leg-wheel robot has mechanically separated four legs and two wheels, and it performs high mobility and stability on rough terrains. The adaptive gait for large rough terrains of the leg-wheel robot is composed of three gait strategies. In this paper, the gait for an upward step, which is one part of the adaptive gait, is described. The proposed method is evaluated by simulations and experiments. The point of the flow of the gait for an upward step is described. When the robot reaches an upward step, it does not come to advance easily because it can not go up the upward step by the normal gait. At this time, the difference between actual wheel angles and desired wheel angles grows. Starting point of the step is detected by using this information. The system stops the body, and prepares for going up the step. In the preparation, the robot changes footsteps in order to set all legs to starting points of their work space. After that, the robot can raise the body on the step supported by all legs and wheels. The purpose of supporting using all legs and wheels is to enhance stability and to reduce energy. To raise the body, the following items are needed: 1 . Acquisition of target rise height of the body. 2. Correspondence to difference between target and actual height.
\end{abstract}

Key Words : Moving Robot, Motion Control, Robot, Gait for an Upward Step, Adaptive Gait, Legwheel Robot, Large Rough Terrain, Gait Strategy

\section{1.は じめに}

脚機構は接地点を任意かつ不連続に取ることが可能 であるため，段差などの踏破性に優れ，斜面や大きな 凹凸がある地形においても機体を安定に支持すること ができる. その一方で, 脚機構は構造が複雑であり, 姿勢制御や脚制御が外界認識情報に強く依存するため, 実用化までには至っていない.

そこで，筆者らは実用化への一つのアプローチとし て，できるだけ低い精度の外界認識情報で，かつ，で きるだけ簡単な制御手法により未知不整地移動を可能 にしようという研究開発思想に基づき, 図 1 に示す 3 自由度の脚を前後に 4 本, 胴体左右に車輪を 2 つ独立 に装備した脚車輪分離型ロボットを研究開発している (1) (2). そして, 凹凸高さが士 $0.1[\mathrm{~m}]$ 程度までの未知の 不整地（通常不整地）における外界センサレス方式の 移動制御手法 ${ }^{(1)}$ を提案してきた。しかし実際には，凹 凸高さが通常不整地より大きい不整地も多く存在する。

筆者らは既に, 脚車輪分離型ロボットが移動すると いう観点から大不整地を体系的に分類し, 大不整地適 応歩容を構成する 3 つの歩容戦略を提案した ${ }^{(9)}$. 本論

\footnotetext{
* 原稿受付 2005 年 8 月 25 日.

*1 正員, 千葉工業大学工学部(㤲275-0016 習志野市津田沼 2$17-1)$

E-mail : shuro.nakajima@it-chiba.ac.jp
}

文では，そのうち，凹凸高さが $0.1 〜 0.2[\mathrm{~m}]$ 程度まで の上り段差不整地を対象にした「段差上り歩容」の制 御手法とその移動能力に関して記述する.

すでに大道らは, 機構的に一部類似した脚車輪口

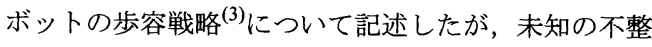
地に対するものではなかった.これに対して本論文で は, 未知の不整地に関する脚車輪分離型ロボットの制 御手法について議論する.

また, 従来の 4 脚または 6 脚の脚式ロボットでは, 脚先からの正確な力情報を用いた力制御を用いること で不整地移動を実現していた ${ }^{(4)-(8)}$ のに対して, 本論文 では各関節の角度センサと胴体姿勢角度センサ（ピッ チ，ロール）の 2 種類の内界センサのみで実現できる 未知不整地の移動制御手法を提案する. カセンサなど の外界センサに頼らない理由は, 屋外の自然環境は, 傾斜や段差，草やぬかるみなどさまざまであり，その 状況を外界センサで判断しても精度が低く，ノイズな どによる判断の誤りも多いためである.つまり，基礎 的な未知不整地移動能力を内界センサの情報のみで確 保する必要が，実用化に向けて必要であるという思想 に基づいている．その上で，必要な外界センサを付加 していくという考え方である. 


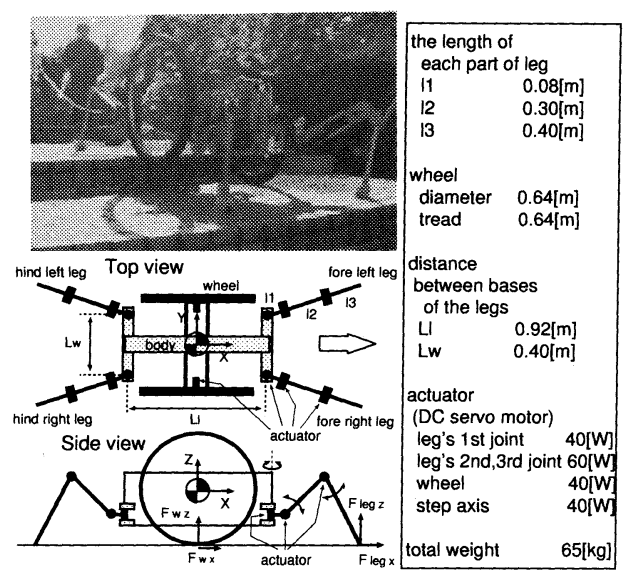

Fig. 1 A leg-wheel robot "Chariot 3"

2. 段差上り歩容の流れ

本論文で対象とする大不整地路面を図 2 に示す０.1 $\sim 0.2[\mathrm{~m}]$ 程度の上り段差を Type A-1 路面とし, 前脚 接地点と車輪接地点の中間の地形が 2 段になった Type A-2 路面, 中間部分が穴地形となった Type A-4, Type A-5 路面である. Type A-4 と Type A-5 は，車輪が穴 に入らないか，または，入るかで分けている，上記の 対象路面の分類方法および選定に関しては，文献 ${ }^{(9)} に$ 記述したため本論文では省略し，名称はそのまま用い た（のほか実在地形を考慮し，第 5 章では，段差に 斜めに進入する場合, 左右段違い上り路面の場合, お よび，なだらかな上り段差の場合も検討した）。

対象とする大不整地を移動する際の歩容形態は,「4 脚全てと車輪で機体を支持して, 機体を段差に上げる」 ものとする.この理由は, 段差に応じて機体を持ち上 げる際には, 安定性・省エネルギ性・推進力と荷重の 分散性などの観点から, 車輪も常時接地して機体を支 持している方が望ましいからである.しかし地形形状 を正確に把握することは困難であり，想定地形と実地 形が異なる場合も多い. そのため車輪の常時接地は前 提とはできず, 脚のみでも静的安定性を確保する必要 がある.さらに, 静的安定性は 3 脚支持でも確保でき るが, 前後および左右方向の外乱への対応力を均等に するため，4脚支持の形態を選択した. なお，この歩 容を「全脚支持歩容」と呼ぶ.

本論文では，上記のように全脚支持歩容により大不 整地を移動する戦略を取るため, 一回の全脚支持歩容 で上れない大きな段差は移動不可能となる.すなわち, 歩幅以上の移動を行わないと上れない段差には対応で きない.ただし本論文では歩幅を $0.35[\mathrm{~m}]$ としており, 対象としている $0.2[\mathrm{~m}]$ 程度までの不整地は十分移動
可能である $(0.2[\mathrm{~m}]$ の段差では $0.297[\mathrm{~m}]$ 移動すれば よい).
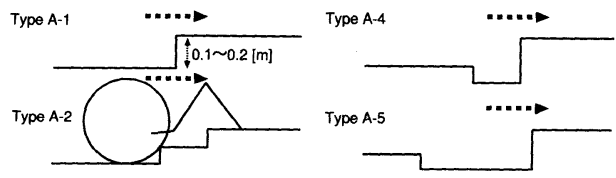

Fig. 2 Targetted rough terrains of the gait for an upward step

図 3 に段差上り歩容の流れを示す.

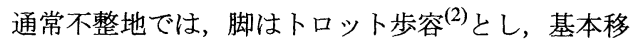
動制御手法 ${ }^{(1)}$ を用いた歩容制御手法（以下，通常歩容 と呼ぶ）を用いている. 通常歩容中に, 上り段差に車 輪が接触すると，機体が進まなくなる，機体が進まな くなると, 後述する車輪角度偏差による判別手法を用 いて上り段差の始点を検知する（図 3(b)）.

段差の始点を検知すると，全脚支持歩容の準備のた めに, 脚の踏換（淮備踏換）を行う。このとき, 全脚 支持歩容での移動距離を最大限確保するために, 全て の脚を可動範囲の始点に踏み換える（図 3(c), (d)). 踏換終了時の脚先位置と胴体の傾きから段差高さを推 定する（図 3(e)）。その後, 全脚支持歩容により，推 定した段差高さだけ胴体を持ち上げる（図 3(f)）.

脚が可動限界に達したことにより全脚支持歩容は終 了し（図 $3(\mathrm{~g})$ ), 通常歩容に遷移するために, 脚の踏 換（終了踏換）を行う（図 3(h)）。はじめの 2 脚が踏 み換えた後, 通常歩容に遷移する（図 3(i)〜 (1)).

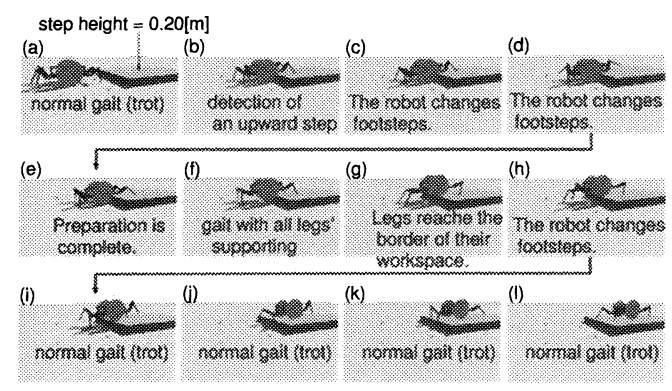

Fig. 3 An image of the gait for an upward step

\section{3. 段差上り歩容の制御手法}

本章では，各段階についての詳細を記述する．

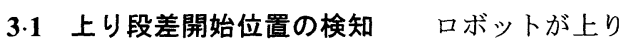
段差に到達すると，通常歩容では段差を上ることが できないために機体が進めなくなる（図 3(b)）。この とき，車輪角度に目標位置からのずれ（車輪角度偏差 $\left.\delta_{w i}\right)$ が生じるため, $\delta_{w i}$ を用いて上り段差開始位置を 検知する. 車輪 $i$ の車輪角度偏差 $\delta_{w i}$ は, $\theta_{\mathrm{wd} i}$ : 車輪 $i$ 
の目標角度, $\theta_{w i}$ : 車輪 $i$ の現在角度として, 次式で 表される.

$$
\delta_{w i}=\theta_{\mathrm{wd} i}-\theta_{w i}
$$

左右車輪の角度偏差の小さい方が，次式のように閾 值 $\Delta_{w \min }$ を越えた時点で上り段差開始位置を検知する.

$$
\min \left(\delta_{w i}\right)>\Delta_{w \min } \quad(i=1,2)
$$

車輪角度偏差の小さい方を用いる理由を記述する. ロボットが通常歩容を行っている場合の左右車輪の角 度偏差は，不整地路面形状により変化する．車輪角度 偏差の大きい方を用いた場合，機体が進めても路面に よっては，閥値を超過する場合がある一方で，車輪角 度偏差の小さい方が閾値を超過した場合には，機体は ほとんどの場合進めない状態だからである.

なお，この判断を処理周期 1 回の結果を用いて行 うと誤検知につながるため, 時系列データ中 $(0.45[\mathrm{~s}]$ 間）の検知割合（8 割以上）を用いて判定を行い，誤 検知の確率を低くした，值は，実験的に決定した。

次に，閾値 $\Delta_{w \min }$ についてであるが，本論文では次 の 2 つのケースによりその値を変えている.

通常不整地の場合（ケース 1)：通常不整地では, 通常歩容で移動可能な限り大不整地適応歩容に 切り換わらない必要がある.そこで，後述する段 差推定值 $H_{e}$ を監視し, 通常不整地 $\left(\max \left(H_{e i}\right)<\right.$ $0.1(i=1,2))$ の場合には閾値 $\Delta_{w \min }$ をケース 2 と比較して大きめ $\left(\Delta_{w \min }=18[\mathrm{deg}]\right)$ に設定する. この值は, 高さ $0.1[\mathrm{~m}]$ 程度の段差までは, 検知 に至りにくいことを各種路面にて試行的に求めた ものである.

大不整地の場合（ケース 2)：大不整地では，なる べく速やかに上り段差開始位置を検知する必要 がある.そこで後述する段差推定值 $H_{e}$ を監視 し, 大不整地 $\left(\max \left(H_{e i}\right) \geq 0.1(i=1,2)\right)$ の場 合には閾值 $\Delta_{w \min }$ をケース 1 と比較して小さめ $\left(\Delta_{w \min }=8[\mathrm{deg}]\right)$ に設定する.これは，0.06[m] の段差程度で検知に至る値である。

ところで，この時点では上り段差が存在するために 機体が動かなくなったのか, 乗り越え歩容 ${ }^{(9)} に$ 遷移す るべき凸地形があるために機体が動かなくなったのか は判断できない，そのため実際には，準備踏換が終了 し, 後述する推定段差高さ $H_{e i}$ を取得した時点で, その 高さにより，段差上り歩容か乗り越え歩容を選択する. 実験の結果, 左右前脚どちらか一方の $H_{e i} \geq 0.05[\mathrm{~m}]$ で段差上り歩容を選択する.

\section{2 段差高さの推定}

3.2.1 脚 $i$ の推定段差高さ 通常歩容では, 前後 脚の遊脚時も含めた可動範囲を確保するため, 前後脚 接地点と車輪接地点から求めた仮想面 ${ }^{(1)}$ に対して胴体 ピッチ角を平行にしている，通常歩容との連続性を考 えて，段差上り歩容でも胴体ピッチ角を仮想面に平行 にする．そのため，段差の高さは仮想面に対する垂直 方向の高さで表す．これを示したのが図 4 である.

図に示すように脚 $i$ の推定段差高さ $H_{e i}$ は, 仮想面 からの凹凸成分に基づく $h_{\text {diff }}$ と仮想斜度（仮想面の斜 度）に基づく $h_{\mathrm{img}}$ に分けて考えられる. なお本論文で は，段差表面が斜面になっている地形は対象外として いるため, 図のように段差は脚接地点から水平に延び ていると仮定する．また段差高さの推定は，前脚のみ 行う.

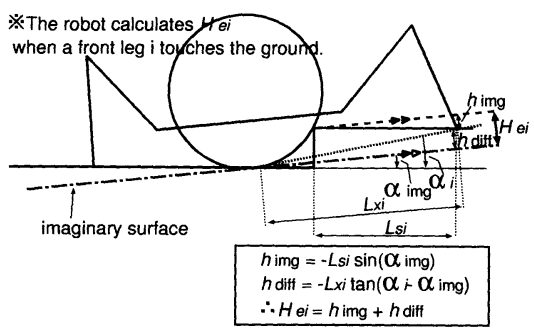

Fig. 4 Estimation of a step height

脚先の接地高さと仮想面との差 $h_{\text {diff }}$ は, $L_{x i}$ を前脚 $i$ の機体座標 $\mathrm{x}$ 方向の脚先位置とし， $\alpha_{i}$ を前脚 $i$ によ る仮想斜度， $\alpha_{\mathrm{img}}$ をその時点のロボットの仮想斜度と すると，

$$
h_{\text {diff }}=-L_{x i} \tan \left(\alpha_{i}-\alpha_{\text {img }}\right)
$$

と表せる.ここで，一は，上り段差の場合を正，下り 段差の場合を負とするためのものである.

またロボットの仮想斜度に基づく推定高さ分 $h_{\mathrm{img}}$ は, 脚先接地点から車輪接地点までの距離を $L_{s i}$ とすると

$$
h_{\mathrm{img}}=-L_{s i} \sin \alpha_{\mathrm{img}}
$$

と表せる. なお本論文では, $L_{s i}$ の近似值として,$L_{x i}$ か ら車輪半径を引いたものを使用した。 これによる誤差 は，誤差が最大となる，段差上り歩容を使う一番低い $0.1[\mathrm{~m}]$ の段差の場合においても $0.005[\mathrm{~m}]$ 程度である.

以上を用いて前脚 $i$ の推定段差高さ $H_{e i}$ は式 (5) と なる. この推定は, 前脚 $i$ が遊脚相から支持相に切り 換わる時点で行う.

$$
H_{e i}=h_{\mathrm{diff}}+h_{\mathrm{img}}
$$

3.2.2 左右段違い段差への対応左右で高さの 異なる段差を上る場合を考える. 図 5 に示すように, 胴体が上る高さは, 左右高さの平均值となる. そこで, 左右前脚の推定段差高さの平均を, 胴体の推定段差高 さ $H_{e}$ とする. 


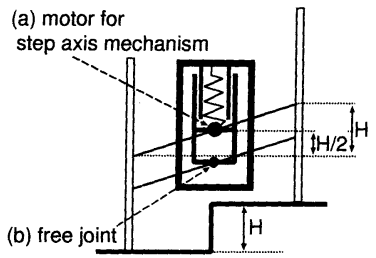

Fig. 5 Height of the body for an uneven step

$$
H_{e}=\left(H_{e f l}+H_{e f r}\right) / 2
$$

ここで, $H_{e \mathrm{fl}}$ : 左前脚の推定段差高さ, $H_{e \mathrm{fr}}$ : 右前脚の 推定段差高さである.

\section{$3 \cdot 3$ 全脚支持歩容における制御準備踏換をし}

て段差高さを推定後, 4 脚全てと両車輪で支持して, 口 ボットが段差を上るための歩容が全脚支持歩容である.

脚の踏換動作により, 全脚が可動範囲の始点に接地 した状態から始まり，全脚と車輪で胴体を持ち上げ， 脚が可動限界に到達した時点で終了する。つまり，1 回の全脚支持歩容により 1 歩幅進むことになる.

\subsection{1 車輪の制御 図 6 は全脚支持歩容時の車} 輪の動きを示したものである．車輪を想定路面に対し て常時接地させるように, 図6の C 点を中心にして回 転させる軌道とする. 図 6 に示す垂直な段差路面を想 定した理由は，なだらかに変化する段差路面を仮定す ると，よりきつい路面と遭遇した場合に，路面と機体 が緩衝して移動しにくいからである.

全脚支持歩容開始時における 1 歩幅分の仮想面は, 図中の A，B，C，Dを結んだ路面となる．ここで，口 ボットのピッチ角は仮想面に平行になるように制御し, 胴体は仮想面と平行に進行すると仮定する．胴体ピッ チ角を仮想面に平行にする理由は, 通常歩容 ${ }^{(1)}$ と同様 に, 遊脚時も含めた前後脚の可動範囲を, ともに大き くするためである.このとき, 車輪 $i$ の微少時間当た りの回転角度 $d W_{d i}$ は, $d P_{\mathrm{xd}}$ を全脚支持歩容時の胴体 の機体座標系 $\mathrm{x}$ 方向の微少時間移動量の目標值, 車輪 半径を $r$ とすると， $\theta$ を図のようにとり，式（7）で表 される.この車輪目標角に対して PD制御を行う.

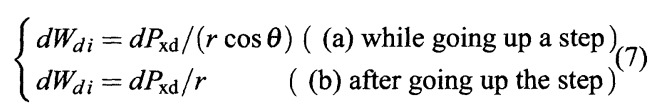

なお $\theta_{s}$ は,「全脚支持歩容開始時の胴体（車輪）中 心と C 点を結ぶ直線」と「C 点を通る仮想面に垂直な 直線」とのなす角度である. また, $d P_{\mathrm{xd}}$ は操縦指令と して与えられ, $H_{e}$ は段差の推定値であり, その他の 值は図に示すように幾何学的に求められる.

ここで，D地点に向かうにつれて実際の路面と仮想 面にずれが生じるが，CD間が最長となり誤差が最大 となる $0.1[\mathrm{~m}]$ の段差でも誤差が $0.003[\mathrm{~m}]$ 程度であり,
脚のコンプライアンスと車輪サスペンションにて十分 吸収できる範囲であるため, 許容している.

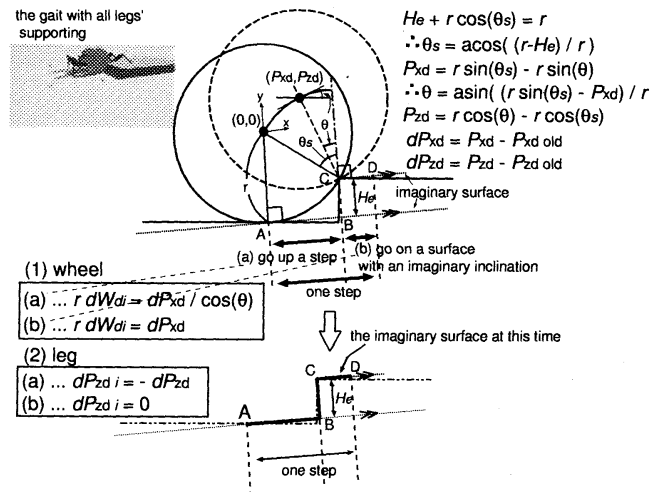

Fig. 6 Wheel and leg control for the gait with all legs' supporting

3.3.2 脚の制御脚軌道についても, 車輪の目標 回転角度の設定と同様に, 胴体の位置 $\left(P_{\mathrm{xd}}, P_{\mathrm{zd}}\right)$ との幾 何学的な関係から設定する.

機体を持ち上げるためには脚を下げる必要があるた め, 脚 $i$ の軌道は, 図 6 より次式で表される.

$$
\begin{cases}d P_{\mathrm{zd} i}=-d P_{\mathrm{zd}} & (\text { (a) while going up a step }) \\ d P_{\mathrm{zd} i}=0 & \text { ( (b) after going up the step })\end{cases}
$$

ここで, $d P_{\mathrm{zd}}$ : 胴体の機体座標系 $\mathrm{z}$ 方向の微少時間移 動量の目標値, $d P_{\mathrm{zd} i}$ : 脚 $i$ の機体座標系 $\mathrm{z}$ 方向の微少 時間移動量の目標値である.

また, 機体座標系 $\mathrm{x}, \mathrm{y}$ 方向の脚先位置は既に提案 した歩容アルゴリズム ${ }^{(2)}$ で決定している.

次に, 脚は離散的に接地するため, 式 (8) に加えて 初期値である接地時の脚先目標位置が必要である. 全 脚支持歩容の場合にも，通常歩容の場合と同様に脚先 にコンプライアンス特性をもたせて多様な路面外乱に 対応させるため, 遊脚相から支持相への切り換わり時

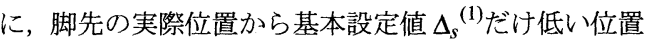
に脚先目標位置を設定する.コンプライアンスの設定 は，通常歩容 ${ }^{(1)}$ と同様にして行い，また，全脚支持歩 容中にも仮想面に胴体ピッチ角が平行になるように， 脚先軌道調整を通常歩容と同じ時期に行う.

3.3.3 段軸の制御通常歩容 ${ }^{(1)}$ と同様に, 安定性 確保のため胴体目標ロール角 $\theta_{\mathrm{d} r}$ を 0 とするように, スカイフックダンパ理論に基づき, 式（9）のフィー ドバック制御を行う。段軸機構は図 5 (a) に示す段軸 機構のモータを制御することで, 胴体ロール角を制御 する機構である.ここで, $T_{\theta_{r}}$ : 段軸機構モ一タのトル ク, $\theta_{r}$ : 胴体ロール角, $\theta_{\mathrm{d} r}$ : 胴体目標ロール角, $K_{r}$, 
$D_{r}$ : 角度ゲインおよび角速度ゲインである.

$$
T_{\theta_{r}}=-K_{r}\left(\theta_{r}-\theta_{\mathrm{d} r}\right)-D_{r}\left(\dot{\theta}_{r}-\dot{\theta_{\mathrm{d} r}}\right)=-K_{r} \theta_{r}-D_{r} \dot{\theta}_{r}
$$

これにより, 以下の理由で段差への斜め進入に対して も対応可能となる。

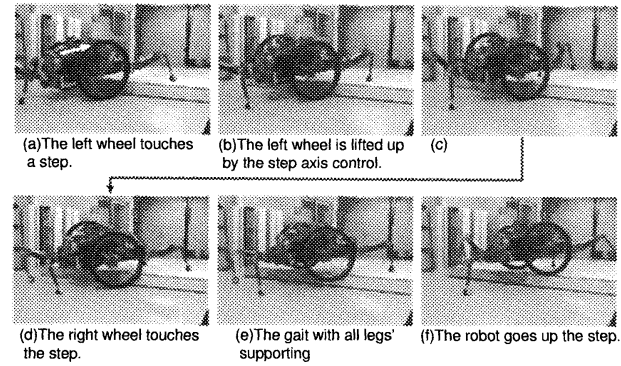

Fig. 7 The effectiveness of step axis control for going up a step diagonally

段差への斜め進入と, 正対しての進入とで異なる点 は，左右車輪が時閒差で段差を上ることである. 図 7 を例に説明すると, 始めに段差を上る左車輪は, 胴体 ロール角を $0[\mathrm{deg}]$ に保とうとする段軸制御により，結 果的に図 (a) 〜 (c) のように持ち上がる. その後, 右 車輪が段差と接触し，段差を上れずに機体が停止する ため, 段差上り歩容となり移動する（図 (d) 〜 (f)).

3.3.4 段差高さ過大推定への対応前脚の接地 位置と車輪接地位置とは離れているために, 地形形状 によっては胴体を上げる高さは正確に推定できない. 例えば図 8 に示した 2 段段差地形の場合は, 全脚支持

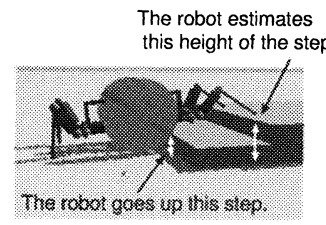

Fig. 8 A terrain of 2 steps

歩容開始時に推定する段差高さ $H_{e}$ は, 実際に機体が 上る段差高さより高い.

推定段差高さ $H_{e}$ の誤差が小さい場合には, 脚先コ ンプライアンスと車輪サスペンションにて吸収できる 一方で，大きい場合には脚先コンプライアンスと車輪 サスペンションでは吸収することができない.

段差高さを過大に推定したことにより機体を上げす ぎ，車輪が接地しない場合を考える（図 9）。全脚支持 歩容中には，4脚での支持により静的安定性が保たれ るが (図 9 (a))，終了踏換期間に脚を上げると，2 脚 支持のため不安定となり最悪の場合倒れてしまう（図 9 (c)).

そこで本論文では，全脚支持歩容終了前に車輪によ る支持がされているかどうかを脚荷重分担率監視アル

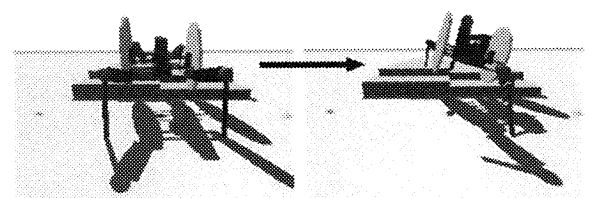

$\begin{array}{ll}\text { (a) The gait with } & \text { (b) The robot had fallen }\end{array}$

all legs' supporting if it chaged footsteps.

Fig. 9 The robot had fallen in case the height of the step was estimated too much.

ゴリズムにより判別し，車輪による支持負担分が少な い場合には, 脚先力弛緩動作により機体を下げて車輪 を接地させることで，これに対応する。

脚荷重分担率監視アルゴリズムとは，次式で表され る脚荷重分担率 $k_{\mathrm{leg}}$ が一定時間中 $d t_{k}$ に，ある割合 $P_{k}$ で閾值 $k_{d}$ を超えると検知する機能である.

$$
k_{\operatorname{leg}}=\frac{\sum_{i=1}^{n}\left(\delta_{z i} / C_{z i}\right)}{W}
$$

ここで, $n$ : 支持脚数, $\delta_{i}$ : 支持脚 $i$ の機体座標系 $\mathrm{z}$ 方向 脚先位置の目標位置との偏差（二[実際位置]-[目標位 置]）, $C_{z i}$ : 支持脚 $i$ の $\mathrm{z}$ 方向コンプライアンス, $W:$ 機 体重量であり, 要するに, ロボットの荷重のうちの脚 で支持する割合を示したものである，本論文では，実 験的に $d t_{k}=0.45, P_{k}=0.8, k_{\mathrm{d} 1}=0.65$ (通常歩容), $k_{\mathrm{d} 2}=0.60$ (全脚支持歩容）とした.

また, 脚先力弛緩動作とは, 脚の目標位置を上昇さ せる（胴体を下げる）ことで, 脚の支持負担力を減少 させるものであり, 機体を停止させた上で, 脚荷重分 担率がある值以下になるまで同体を下げる動作である.

\subsection{5 推定段差高さ不足への対応前脚の接地} 位置と車輪接地位置との間に凸地形が存在する場合に は, 推定段差高さ $H_{e}$ は, 実際に胴体が上る段差高さ より低くなる.

そのため, 推定誤差が大きい場合には胴体が段差を 上がることができない，そこで，胴体が段差を上れな いと判断した場合には次の戦略をとる.

胴体が段差を上れないことの判断は，全脚支持歩容 期間の車輪角度の目標位置からの偏差を監視すること で行う. 偏差が大きくなり, 上れないと判断した場合 には, 乗り越え歩容 ${ }^{(9)} に$ 遷移し, 移動を達成する. な お，この動作の詳細については別の論文にて記述する ため,ここでは省略する。

\section{4. シミュレーションと実験}

本章では，提案する歩容制御手法にて，対象とする 大不整地路面の移動が可能であることを検証する.

以下のシミュレーションおよび実験条件として, 遊脚 の脚先速さ $0.5[\mathrm{~m} / \mathrm{s}]$, 遊脚時の脚上げ高さ $0.2[\mathrm{~m}]$, 遊 
脚の接地検出するまでの最大脚下げ深さ $0.4[\mathrm{~m}]$, 歩 幅 $0.35[\mathrm{~m}]$, 脚先の目標位置と実際位置の基本偏差 $\Delta_{S}=0.043[\mathrm{~m}]$, 全脚先合計の機体座標 $\mathrm{z}$ 方向の脚先剛 性および車輪サスペンション剛性 $7500[\mathrm{~N} / \mathrm{m}]$, 脚と車 輪の基本荷重分担率 $1: 1$, 車輪回転制御の $\mathrm{P}$ ゲイン $80[\mathrm{Nm} / \mathrm{rad}], \mathrm{D}$ ゲイン $20[\mathrm{Nm} / \mathrm{rad} / \mathrm{s}]$, 段軸制御の P ゲ イン $1000[\mathrm{Nm} / \mathrm{rad}], D$ ゲイン $100[\mathrm{Nm} / \mathrm{rad} / \mathrm{s}]$, 環境は 未知とし，脚にはトロット歩容 ${ }^{(2)}$ を行わせた．また， シミュレーションは動力学シミュレーションソフトで ある ODE（Open Dynamics Engine）を用い，条件とし て, 脚および車輪と路面の接触は剛体で, 脚と路面の 摩擦係数は 0.4 , 車輪と路面の摩擦係数は 0.7 とした.

\subsection{Type A-1 路面}

4.1.1 シミュレーション（Type A-1） 図 10 (a) に示す, 高さ $0.20[\mathrm{~m}]$ の未知の上り段差が存在する路 面に対する移動シミュレーションを行った. 図 10 (b) はそのときの様子を示したものであり, $0.20[\mathrm{~m}]$ の末 知上り段差の移動が実現できていることがわかる.

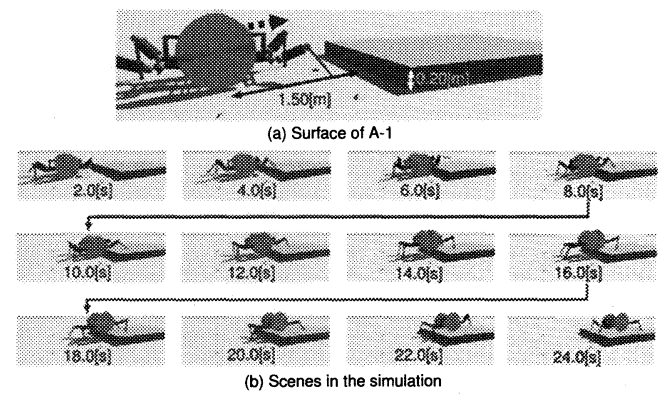

Fig. 10 Scenes in the simulation ( Type A-1 terrain )

\section{そのときのデータを図 11 (a) 〜 (f) に示す.}

図 11 (a) は, 機体の目標直進速度である. 図中（1） の速度 $V_{\text {body }}=0$ では, 脚の踏換を行っており, (2) に おいて全脚支持歩容を行っている. 目標速度の小さな

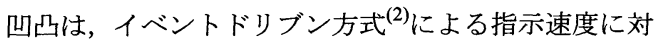
する制限の結果である. また，(3) で速度 $V_{\text {body }}=0$ と なっているのは, 通常歩容時に動作した脚先力弛緩動 作によるものであり，このとき，図 $11 （ \mathrm{~d} ）$ の（6）で 検知後, 脚荷重分担率 $k_{\operatorname{leg}}$ が減少している.

図 11 (b) には, 胴体ピッチ, ロール角の推移を示 した. 図より, 胴体ピッチ角は仮想斜度に追随し, 胴 体ロール角は水平を保った移動ができていることがわ かる.

図 11 (c) には, $\mathrm{t}=0 \sim 9[\mathrm{~s}]$ における左右車輪角度の 目標角度からのずれ（㫫輪角度偏差）を示した. 図中 （4）において, 車輪角度偏差の小さい左車輪の角度偏 差が，閥値 $8[\mathrm{deg}]$ を $0.45[\mathrm{~s}]$ の間に超過する割合が,
閾値 0.8 （上記値は実験的に選定）を超えることによ り，上り段差始点を検知する. 検知後は車輪角度の目 標值を現在位置にリセットし, 車輪角度偏差は一度 0 となる.

図 $11(\mathrm{~d})$ には, 脚荷重分担率 $k_{\operatorname{leg}}$ の $\mathrm{t}=10 \sim 27[\mathrm{~s}]$ に おける推移を示した. 図中（5）で，全脚支持歩容が終 了する直前に，機体を持ち上げ過ぎていないかの判定 のために, 閾値 $k_{\mathrm{d} 2}(=0.6)$ と比較する. 今回は閾值を 超えていないために, 機体を持ち上げ過ぎていないと 判断し, 脚先力弛緩動作には入らない. 図中（6）の 通常歩容時には, 閾値 $k_{\mathrm{d} 1}(=0.65)$ に対して脚荷重分 担率監視機能が働き, 機体を停止させ脚先力弛緩動作 をする. その結果 $k_{\operatorname{leg}}$ は, 目標値 0.5 付近まで下がる.
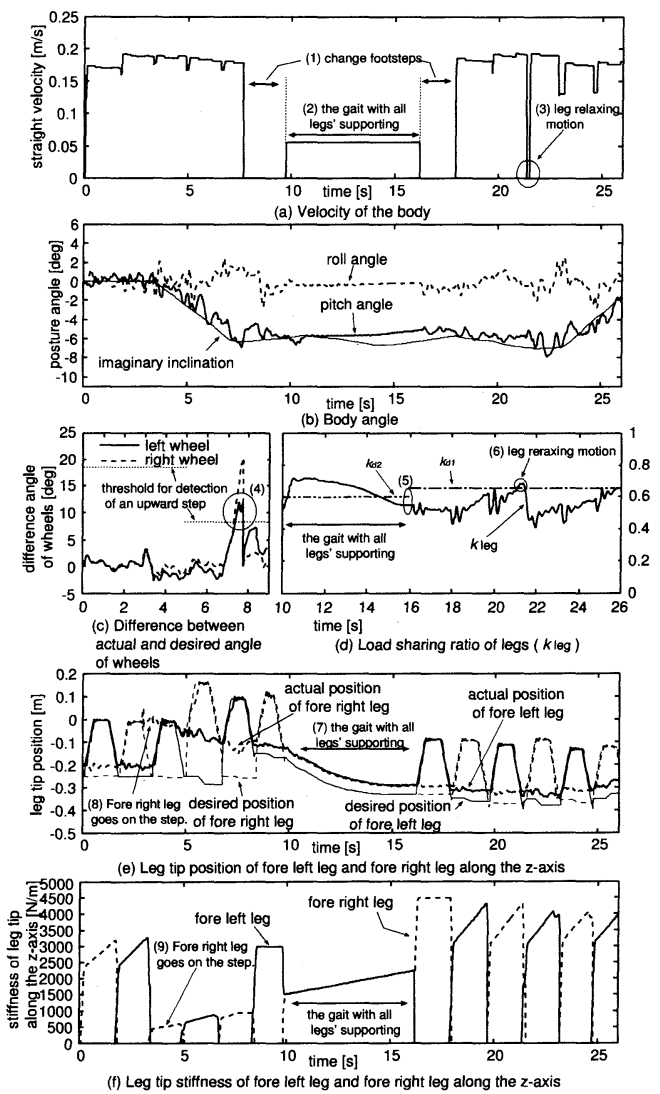

Fig. 11 Simulation data ( Type A-1 terrain )

図 11 (e) には, 左右前脚の脚先の機体座標 $\mathrm{z}$ 方向 の目標位置と実際位置を示した. 図中（7）の全脚支 持歩容時には, 機体を持ち上げるために, 各脚の目標 位置を下げていることがわかる. 段差高さの推定值 $H_{e}$ は $0.179[\mathrm{~m}]$ と計算され, この分だけ目標位置を下げ ている. なお参考のため, 段差高さ $0.2[\mathrm{~m}]$ の場合の 
$H_{e}$ の理論值は $0.181[\mathrm{~m}]$ である. 目標位置と実際位置 の偏差は, コンプライアンスを設定しているためであ り，全脚支持歩容時にもコンプライアンスを持ったま ま，脚先が制御されていることがわかる．図中（8）で は, 右前脚が段差上に接地したため, 脚先位置の偏差 が大きくなっている.

図 11 （f）には，左右前脚（支持脚時）の脚先の剛性 を示した. 遊脚相における脚先剛性は, 見やすさのた め0 と表示している. 全脚支持歩容時には, 全脚で支 持するため各脚の脚先剛性は小さくなっている. 図中 （9）で右前脚の剛性が小さくなっている理由は, 図 11 （e）（8）で脚先位置偏差が大きくなり, 脚先に余分な 力が生じないよう剛性を調整しているからである.

4.1.2 実験（Type A-1） 図 12（a）に示寸高さ $0.20[\mathrm{~m}]$ の上り段差路面に対する移動実験を行った.こ れは, 図 10 と同じ地形である. (b) はそのときの様子 を示したものであり, 実験機でも $0.20[\mathrm{~m}]$ の未知上り 段差の移動が実現できている.
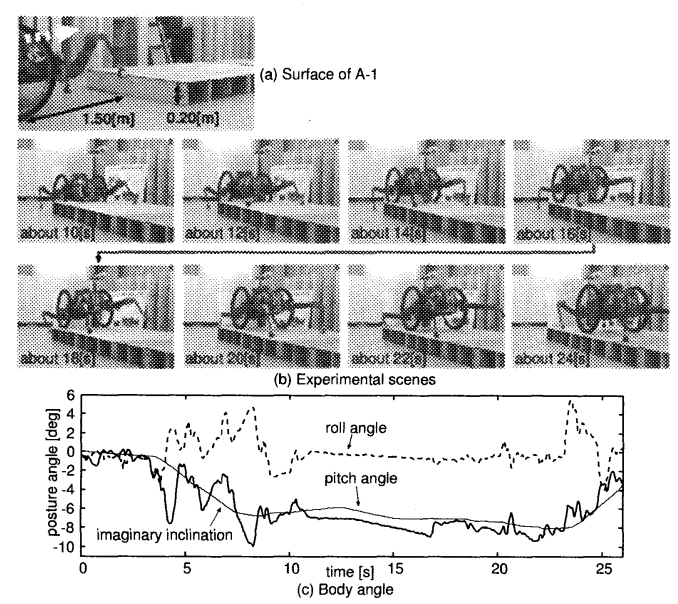

Fig. 12 Experimental scenes ( Type A-1 terrain ) 紙面の都合上, 胴体姿勢角度データのみ図 12 (c) に示した. 実験時の胴体姿勢角の推移傾向は, シミュ レーションとほぼ同様であった。 なお, 実験データの 胴体姿勢角が, シミュレーションデータに比べて大き く変化している理由については, 関節摩擦の影響や脚 と機体に関するモデル誤差などによるものと考えてい る. 推定段差高さは $H_{e}=0.174$ であった. また, その 他の実験データも, シミュレーションデータとほぼ同 様であることを確認した。

\section{5. その他の不整地での移動実験の様子}

本章では, 図 2 に示したその他の対象路面, および, 段差に斜めに進入する場合, 左右段違い上り路面の場
合，そして，なだらかな上り段差の場合の移動実験に ついて記述する. 全ての対象路面についてシミュレー ションと実験を行い, 移動能力を検証し確実に移動で きることを確認したが, 紙面の都合上, 実験の様子の みを揭載する。

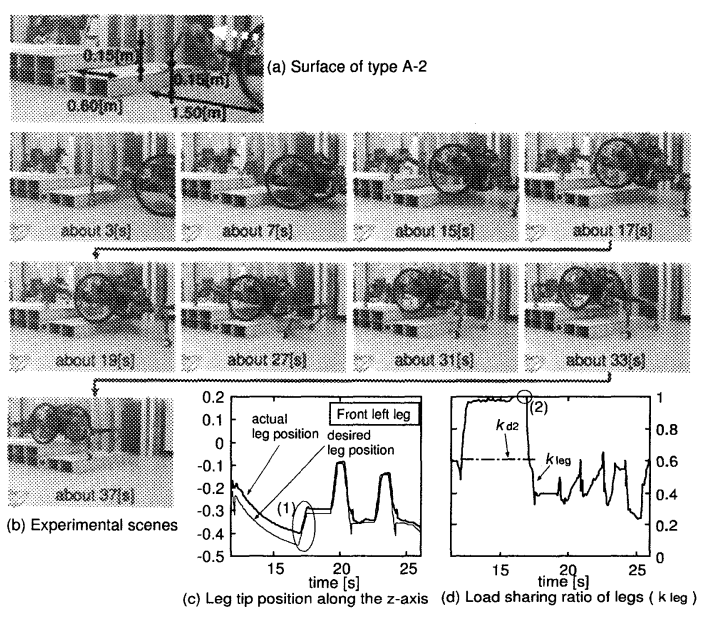

Fig. 13 Type A-2 terrain

$5 \cdot 1$ Type A-2 路面 1 段目の奥行きが $0.60[\mathrm{~m}]$ である高さ $0.15[\mathrm{~m}]$ の 2 段の段差路面（図 13 (a)）に 対する移動実験の様子（図 $13(\mathrm{~b})$ ) を示す. 推定段差 高さ $H_{e}$ は， 1 段目で $0.230[\mathrm{~m}], 2$ 段目で $0.131[\mathrm{~m}]$ で あった. 図 13 (c) には, 左前脚の機体座標 $\mathrm{z}$ 方向の 脚先の実際位置と目標位置を示す. 1 段目の段差上り 歩容では, 前脚は 2 段目に接地するが, 胴体は 1 段し か上らないために, 過大な推定段差高さとなり胴体を 上げすぎる，そのため，図中（1）で脚先目標位置を 上げることで, 胴体を下げて対忘している. 図 13 (d) は，そのときの脚荷重分担率 $k_{\mathrm{leg}}$ の推移を示したもの である. 図中（2）の全脚支持歩容終了時に $k_{\mathrm{leg}}$ が閾 值 $k_{\mathrm{d} 2}$ よりも高いため, 図 13 (c)（1）により胴体を 下げ, その後の脚荷重分担率が減少し, 車輪は接地す る. その結果, 安定した移動が実現できる.

5.2 Type A-4 路面 図 14 (1-a) に示す, 上り段 差の前に車輪半径程度の穴地形が存在する路面に対す る移動実験（図 14 (1-b)）を行った. 車輪が穴に入る ことがないため, Type A-1 路面と同様に移動した.

5.3 Type A-5 路面 図 14 (2-a) に示す, 上り 段差の前に車輪直径程度の穴地形が存在する路面に対 する移動実験（図 14 (2-b)) を行った. 車輪が穴に入 るが, 通常歩容にて段差までは移動し, その後, Type A-1 路面と同様にして移動した.

5.4 段差への斜め進入 段差に対して斜めに進 入する場合に，垂直に進入する場合と比較して異なる 
点は，段差の始点位置が左右で異なることである.

そこで, 図 14 (3-a) に示すように, 高さ $0.15[\mathrm{~m}]$ の 段差の開始位置が左右で $0.2[\mathrm{~m}]$ ずれている路面につ いて実験（図 14.(3-b)) を行った. 左車輪は通常歩 容で上り，右車輪が段差に接地した後，機体が上らな くなるために段差上り歩容に遷移し，移動した．

\section{5 左右段違い上り路面 図 14 (4-a) に示す左} 右段違い上り路面に対して実験（図 14 (4-b)) を行っ た. 左右路面の高さが異なるにもかかわらず，段軸制 御により胴体ロール角はほぼ水平のまま移動できてい ることがわかる。

5.6 なだらかな上り段差路面図14（5-a）に示 すなだらかな上り段差地形に対して実験（図 14 (5-b)) を行った.このときも, 想定地形との差をコンプライ アンスで吸収することで，移動できた．なお，長い斜 め段差地形に対しても，脚の踏換中に車輪が確実に接 地できる地形があれば, 複数回の段差上り歩容を行う ことで移動できることを実験により確認した.

\section{6.お わりに}

本論文では, 脚車輪分離型ロボットの大不整地適応 歩容の一つである段差上り歩容に関して, その制御手 法を提案した。 そして，提案した段差上り歩容が対象 とする大不整地地形について，シミュレーションと実 験により移動能力を検証した. 全ての対象路面に対し て，シミュレーションと実験をそれぞれ行い，確実に 移動できることを確認した（本報告では紙面の都合上， 一部のデータと実験の様子を掲載するにとどまった）.

今後の課題としては, 大不整地適応歩容の残り $2 つ$ の移動戦略（段差下り歩容, 乗り越え歩容)について 提案し，その移動能力を検証することである．別の論 文にて詳細に報告したい.

\section{文献}

(1) Nakajima,S. et al., The Motion Control Method for a Leg-wheel Robot on Unexplored Rough Terrains, "Journal of the Robotics Society of Japan", vol.22, no.8, (2004), pp.1082-1092.

(2) Nakajima,S. et al., Trot and Pace Gaits based on the Predictive Event Driven Method for a Leg-wheel Robot, "Journal of the Robotics Society of Japan", vol.22, no.8, (2004), pp.1070-1081.

(3) Ohmichi,T. and Ibe,T., Development of Vehicle with Legs and Wheels, "Journal of the Robotics Society of Japan", vol.2, no.3, (1984), pp.244-251.

(4) S. M. Song and K. J. Waldron, Machines That Walk:The Adaptive Suspension Vehicle, "MIT Press", (1989).

(5) K. K. Hartikainen, A. J. Halme, H. Lehtinen and K. O. Koskinen, MECANT I:A Six Legged Walking Machine for Research Purposes in Outdoor Environment,
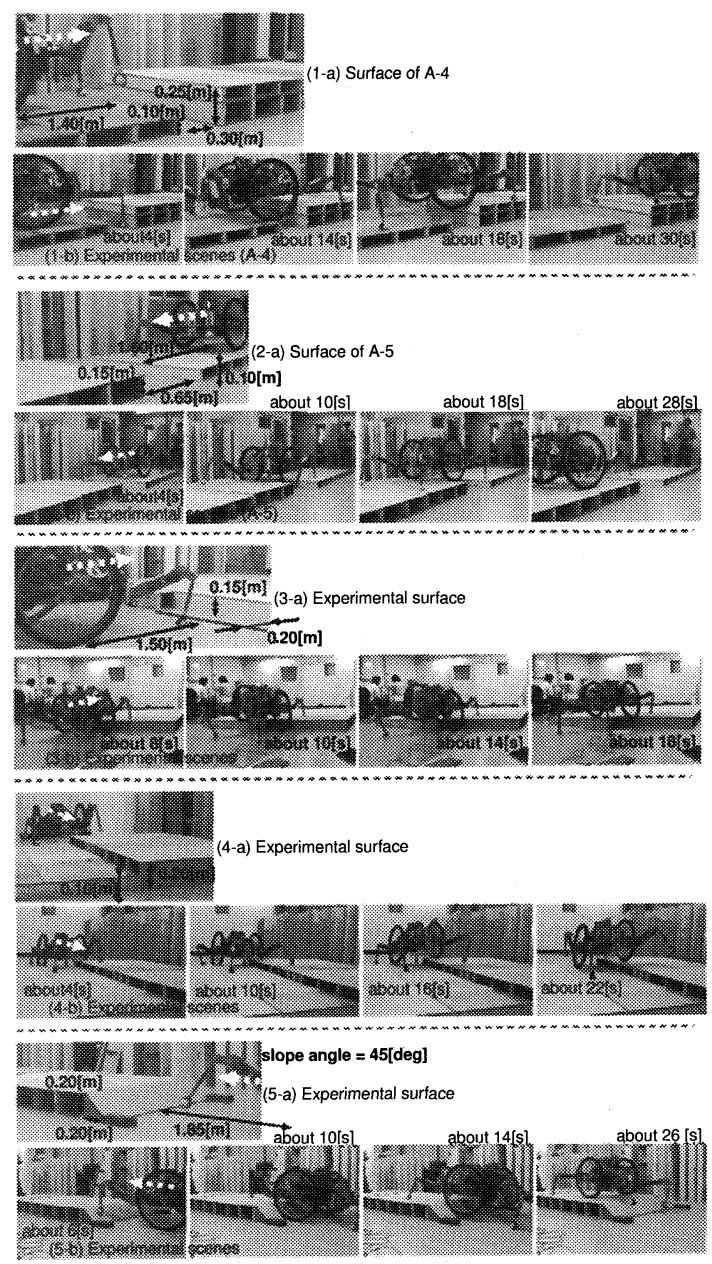

Fig. 14 Other rough terrains

"Proceedings of the 1992 IEEE International Conference on Robotics and Automation", (1992), pp.157-163.

(6) D. M. Gorinevsky and A. Shneider, Force Control of Legged Vehicles over Rigid and Soft Surfaces, "International Journal of Robotics Research", vol.9, no.2, (1990), pp.4-23.

(7) J. E. Bares, W. L. Whittaker, Configuration of Autonomous Walkers for Extreme Terrain, "The International Journal of Robotics Research", vol.12, no.6, (1993), pp.535-559.

(8) T. Hori, et al., Force Control for Hexapod Walking Robot with Torque Observer, "Proceedings of the International Conference on Intelligent Robots and Systems", (1994), pp.1294-1300.

(9) Nakajima,S. and Nakano,E., Adaptive Gait for Large Rough Terrain of a Leg-wheel Robot (1st Report: Gait Strategy), "Nihon Kikai Gakkai Ronbunshu, C (Transactions of the Japan Society of Mechanical Engineers, Series C)", vol. 72, no. 721, (2006), pp. 2926-2931. 